\title{
The performance of institutional of dairy cattle farmers and their effects on financial, technological, and physical resources
}

\author{
Soetriono ${ }^{1)}$ and Amam $^{* 1,2)}$ \\ 1) Department of Agribusiness, Faculty of Agriculture, Universitas Jember, \\ Jember, Jawa Timur, 68121, Indonesia \\ ${ }^{2)}$ Department of Animal Husbandry, Faculty of Agriculture, Universitas Jember, \\ Bondowoso, Jawa Timur, 68251, Indonesia
}

Submitted: 24 September 2019, Accepted: 5 March 2020

\begin{abstract}
The Performance of Institutional give influences to the development of livestock business, and influenced by farmers' access to various resources. The purpose of this study is to examine the institutional performance of dairy farmers and analyze their effects on resources. The study was conducted in May to September 2019 in Pujon Subdistrict, Malang Regency, East Java Province. Respondents are all breeders of Tirtasari Kresna Gemilang KUB (Joint Business Group) of 174 people. The method of collecting data uses FGD (Focus Group Discussion), observation, and survey. The survey was conducted by interview and questionnaire. The variables of research consisted of institutional performance $(\mathrm{X})$, financial resources $\left(\mathrm{Y}_{1}\right)$, technological resources $\left(\mathrm{Y}_{2}\right)$, and physical resources $\left(\mathrm{Y}_{3}\right)$. Data were analyzed using the PLS (Partial Least Square) method. The results showed that institutional performance affected financial, technological, and physical resources, respectively 0.414, 0.367, and 0.289. The conclusion of the research is the institutional performance of dairy farmers with a positive and significant effect on financial resources, technological resources, and physical resources.
\end{abstract}

Keywords: Group dynamics; Livestock groups, resources; Livestock businesses

*Corresponding Author: amam.faperta@unej.ac.id 


\section{INTRODUCTION}

Government Regulation Number 6 of 2013 concerning Farmer Empowerment defines farmer empowerment as an effort made by the government, provincial government, district/city government, and stakeholders in the field of animal husbandry and animal health to increase independence, provide convenience, and business progress, and increase power competitiveness and welfare of farmers.

One of the efforts to empower farmers is through the institution of farmers. Farmer Institution is a organization of farmers in conducting livestock farming business activities in agribusiness, from upstream to downstream, as well as building relationships with various stakeholders. The role of institutions is significant to realize cooperation and network relations with stakeholders as an effort to build and strengthen institutions (Amam et al., 2020). These efforts aim to encourage the growth of livestock farming businesses that are more efficient, effective, and sustainable. Hasdi et al. (2015) states that the institutional aspect is one dimension of the sustainability of livestock farming business in addition to the technological, environmental, economical, and cultural dimensions.

Good and bad performance of farmer institutions is expressed as an institutional performance. Amam and Harsita (2019) state that institutional performance has a positive and significant effect on the quality of human resources (Farmers). It means that the existence of farmer institutions as a forum for empowerment of farmers is something that supports the improvement of the quality of farmers HR. Sutanto and Hendraningsih (2011) revealed that the institutional role of dairy farmers is still lacking by farmers, particularly the institutional role in extension activities, banking access, microfinance, and the level of member involvement in the group. The farmer institutional performance has a positive effect on the development of livestock businesses and negatively affects business risk aspects (Amam and Soetriono). Other sources state that livestock farming business development is influenced by resources (Amam et al., 2019) so that the accessibility of farmers to resources plays an important role in the development of livestock farming businesses (Amam et al., 2019). These resources include financial resources, technological resources, and physical resources (Amam et al., 2019). Andarwati et al. (2017) revealed that the combination of the use of financial assets, physical assets and natural resources is one of the most dominant strategies chosen by dairy farmers. This study aims to examine the institutional performance of dairy farmers and analyze their effects on resources. The resources referred to in this study are financial resources, technological resources, and physical resources (Amam et al., 2019). The study was conducted at the institutional dairy farmers, namely KUB (Joint Business Group) Tirtasari Kresna Gemilang. KUB Tirtasari Kresna Gemilang is an institutional dairy farmer that is legally registered and has a legal entity number 0010084AH.01.07.

Based on the description, this research hypothesizes that the institutional performance of dairy farmers has a positive effect on financial resources, technological resources, and physical resources. The novelty of this study is to examine the institutional role of dairy farmers to the accessibility of farmers in various resources. Amam et al. (2019) states that resources have an important role in the development of livestock farming businesses.

\section{MATERIALS AND METHODS}

This research model uses the ex post facto research approach. The study was conducted in May to September 2019 in Malang Regency, East Java Province. Malang Regency is one of the National Dairy Farm Areas (KPSPN) following the Decree of the Minister of Agriculture of the Republic of Indonesia Year 2015 Number 43/Kpts/PD.010/1/2015 concerning the 
Establishment of Beef Cattle, Buffalo, Goat, Dairy Cattle, Sheep, and National Pork. This study conducted at KUB (Kelompok Usaha Bersama as Joint Business Group) Tirtasari Kresna Gemilang. KUB Tirtasari Kresna Gemilang was used as a research sample because the institution was legally registered and has a legal entity number 0010084-
AH.01.07, so the sample selection was determined by purposive sampling. Respondents were all breeders of KUB Tirtasari Kresna Gemilang. The total number of respondents was 174 dairy farmers (total sampling). Data is collected using the FGD (Focus Group Discussion), observation, and survey methods.

Table 1. Research variables and indicators

\begin{tabular}{|c|c|c|}
\hline Variable & Indicator & Notation \\
\hline \multirow{6}{*}{$\begin{array}{l}\text { Institutional } \\
\text { performance }(\mathrm{X})\end{array}$} & group facilities & $\mathrm{X}_{1.1}$ \\
\hline & achievement of the group goals & $\mathrm{X}_{1.2}$ \\
\hline & functions and group tasks & $\mathrm{X}_{1.3}$ \\
\hline & group structure & $\mathrm{X}_{1.4}$ \\
\hline & group harmony & $\mathrm{X}_{1.5}$ \\
\hline & institutional form & $\mathrm{X}_{1.6}$ \\
\hline \multirow{14}{*}{$\begin{array}{ll}\text { Financial resources } \\
\left(\mathrm{Y}_{1}\right)\end{array}$} & main income & $\mathrm{Y}_{1.1}$ \\
\hline & income of dairy cattle business & $\mathrm{Y}_{1.2}$ \\
\hline & income of businesses other than livestock & $\mathrm{Y}_{1.3}$ \\
\hline & income of other livestock businesses & $\mathrm{Y}_{1.4}$ \\
\hline & total income for daily necessities & $\mathrm{Y}_{1.5}$ \\
\hline & amount of savings & $\mathrm{Y}_{1.6}$ \\
\hline & amount of debt & $\mathrm{Y}_{1.7}$ \\
\hline & debt service & $\mathrm{Y}_{1.8}$ \\
\hline & ownership of calf & $\mathrm{Y}_{1.9}$ \\
\hline & ownership of virgin cattle & $Y_{1.10}$ \\
\hline & ownership of pregnant cow & $\mathrm{Y}_{1.11}$ \\
\hline & ownership of production cattle & $\mathrm{Y}_{1.12}$ \\
\hline & ownership of dry period cattle & $\mathrm{Y}_{1.13}$ \\
\hline & the number of cattle populations kept & $\mathrm{Y}_{1.14}$ \\
\hline \multirow{6}{*}{$\begin{array}{l}\text { Technological } \\
\text { resources }\left(\mathrm{Y}_{2}\right)\end{array}$} & selection of broodstock (breeding) & $\mathrm{Y}_{2.1}$ \\
\hline & feed technology & $\mathrm{Y}_{2.2}$ \\
\hline & livestock health & $\mathrm{Y}_{2.3}$ \\
\hline & cage & $\mathrm{Y}_{2.4}$ \\
\hline & milk marketing & $Y_{2.5}$ \\
\hline & technology for increasing milk production & $\mathrm{Y}_{2.6}$ \\
\hline \multirow{10}{*}{$\begin{array}{ll}\text { Physical resources } \\
\left(\mathrm{Y}_{3}\right)\end{array}$} & home of residence & $\mathrm{Y}_{3.1}$ \\
\hline & cowshed & $Y_{3.2}$ \\
\hline & means of transportation & $\mathrm{Y}_{3.3}$ \\
\hline & means of communication & $\mathrm{Y}_{3.4}$ \\
\hline & means of information & $\mathrm{Y}_{3.5}$ \\
\hline & electric usage & $\mathrm{Y}_{3.6}$ \\
\hline & land tenure & $\mathrm{Y}_{3.7}$ \\
\hline & land use & $\mathrm{Y}_{3.8}$ \\
\hline & availability of water sources & $Y_{3.9}$ \\
\hline & availability of feed sources & $\mathrm{Y}_{3.10}$ \\
\hline
\end{tabular}


The survey method was carried out by interviewing and filling in the questionnaire. The questionnaire used was Likert scale +1 to +5 . This study consists of four main variables, namely institutional performance $(\mathrm{X})$, financial resources $\left(\mathrm{Y}_{1}\right)$, technological resources $\left(\mathrm{Y}_{2}\right)$, and physical resources $\left(\mathrm{Y}_{3}\right)$. Indicators of each variable are described in
Table 1. Based on the description of variables and indicators in Table 1 , the variable relationship model is presented in Figure 1. Based on the description of the variables and indicators in the Table, as well as the Variable Relationship Model in Figure 1, the form of the mathematical equation is as follows.

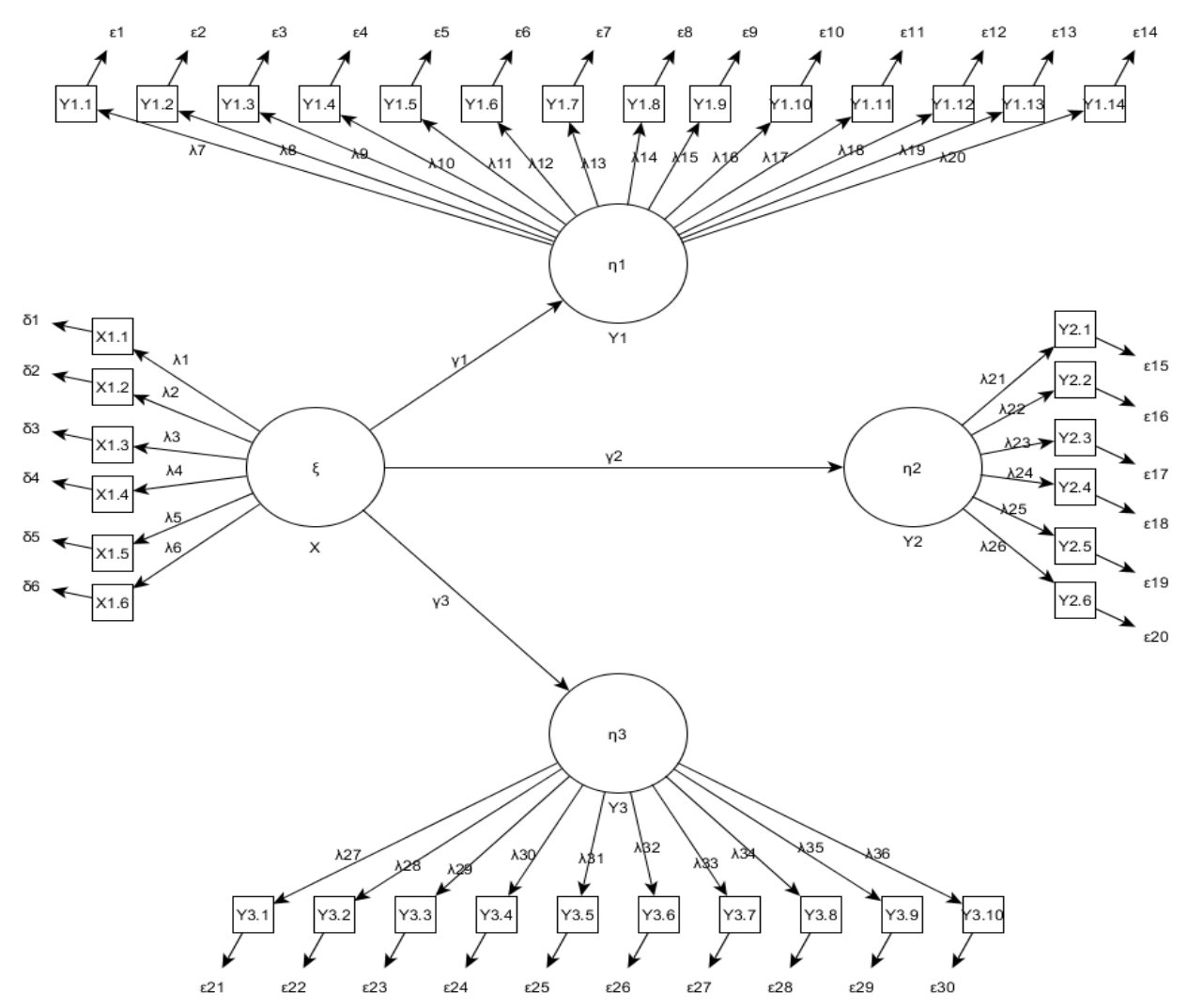

Figure 1: Variable Relationship Model

Latent Variable endogen/reflective (X)

$$
\begin{aligned}
& \mathrm{X}_{1.1}=\left(\lambda_{1} \xi_{1}\right)+\delta_{1} \quad \mathrm{X}_{1.4}=\left(\lambda_{4} \xi_{1}\right)+\delta_{4} \\
& \mathrm{X}_{1.2}=\left(\lambda_{2} \xi_{1}\right)+\delta_{2} \quad \mathrm{X}_{1.5}=\left(\lambda_{5} \xi_{1}\right)+\delta_{5} \\
& \mathrm{X}_{1.3}=\left(\lambda_{3} \xi_{1}\right)+\delta_{3} \quad \mathrm{X}_{1.6}=\left(\lambda_{6} \xi_{1}\right)+\delta_{6}
\end{aligned}
$$

Latent Variable endogen/reflective ( $\left.\mathrm{Y}_{1}\right)$

$$
\begin{aligned}
& Y_{1.1}=\left(\lambda_{7} \eta_{1}\right)+\varepsilon_{1} \quad Y_{1.6}=\left(\lambda_{12} \eta_{1}\right)+\varepsilon_{6} \quad Y_{1.11}=\left(\lambda_{17} \eta_{1}\right)+\varepsilon_{11} \\
& Y_{1.2}=\left(\lambda_{8} \eta_{1}\right)+\varepsilon_{2} \quad Y_{1.7}=\left(\lambda_{13} \eta_{1}\right)+\varepsilon_{7} \quad Y_{1.12}=\left(\lambda_{18} \eta_{1}\right)+\varepsilon_{12} \\
& \mathrm{Y}_{1.3}=\left(\lambda_{9} \eta_{1}\right)+\varepsilon_{3} \quad \mathrm{Y}_{1.8}=\left(\lambda_{14} \eta_{1}\right)+\varepsilon_{8} \quad \mathrm{Y}_{1.13}=\left(\lambda_{19} \eta_{1}\right)+\varepsilon_{13} \\
& Y_{1.4}=\left(\lambda_{10} \eta_{1}\right)+\varepsilon_{4} \quad Y_{1.9}=\left(\lambda_{15} \eta_{1}\right)+\varepsilon_{9} \quad Y_{1.14}=\left(\lambda_{20} \eta_{1}\right)+\varepsilon_{14} \\
& Y_{1.5}=\left(\lambda_{11} \eta_{1}\right)+\varepsilon_{5} \quad Y_{1.10}=\left(\lambda_{16} \eta_{1}\right)+\varepsilon_{10}
\end{aligned}
$$

Latent Variable endogen/reflective $\left(\mathrm{Y}_{2}\right)$

$$
\begin{array}{rlll}
\mathrm{Y}_{2.1} & =\left(\lambda_{21} \eta_{2}\right)+\varepsilon_{15} & \mathrm{Y}_{2.4} & =\left(\lambda_{24} \eta_{2}\right)+\varepsilon_{18} \\
\mathrm{Y}_{2.2} & =\left(\lambda_{22} \eta_{2}\right)+\varepsilon_{16} & \mathrm{Y}_{2.5} & =\left(\lambda_{25} \eta_{2}\right)+\varepsilon_{19} \\
\mathrm{Y}_{2.3} & =\left(\lambda_{23} \eta_{2}\right)+\varepsilon_{17} & \mathrm{Y}_{2.6} & =\left(\lambda_{26} \eta_{2}\right)+\varepsilon_{20}
\end{array}
$$


Latent Variable endogen/reflective $\left(\mathrm{Y}_{3}\right)$

$\begin{array}{rlllll}\mathrm{Y}_{3.1} & =\left(\lambda_{27} \eta_{3}\right)+\varepsilon_{21} & \mathrm{Y}_{3.5} & =\left(\lambda_{31} \eta_{3}\right)+\varepsilon_{25} & \mathrm{Y}_{3.8} & =\left(\lambda_{34} \eta_{3}\right)+\varepsilon_{28} \\ \mathrm{Y}_{3.2} & =\left(\lambda_{28} \eta_{3}\right)+\varepsilon_{22} & \mathrm{Y}_{3.6} & =\left(\lambda_{32} \eta_{3}\right)+\varepsilon_{26} & \mathrm{Y}_{3.9} & =\left(\lambda_{35} \eta_{3}\right)+\varepsilon_{29} \\ \mathrm{Y}_{3.3} & =\left(\lambda_{29} \eta_{3}\right)+\varepsilon_{23} & \mathrm{Y}_{3.7} & =\left(\lambda_{33} \eta_{3}\right)+\varepsilon_{27} & \mathrm{Y}_{3.10} & =\left(\lambda_{36} \eta_{3}\right)+\varepsilon_{30} \\ \mathrm{Y}_{3.4} & =\left(\lambda_{30} \eta_{3}\right)+\varepsilon_{24} & & & & \end{array}$

Latent Variable exogen/formative

$\mathrm{Y}_{1}=\left(\eta_{1} \gamma_{1}\right)+\varepsilon$

$\mathrm{Y}_{2}=\left(\eta_{2} \gamma_{2}\right)+\varepsilon$

$\mathrm{Y}_{3}=\left(\eta_{3} \gamma_{3}\right)+\varepsilon$

\section{RESULTS AND DISCUSSION Outer Model}

The PLS (Partial Least Square) method is used to test the indicators of each variable. The indicator test results are called outer loading values. Outer loading value that meets the requirements and is considered valid is $>0.500$, if the outer loading value $<0.500$, then the indicator is declared invalid and does not meet the requirements. The results of testing of various indicators are described in Table 2.

Testing the outer model produces various criteria consisting of the Average Variance Extracted (AVE) value, the Cronbach's Alpha (CA) value, and the $\mathrm{R}$ Square value (R2). The results of these criteria tests are described in Table 3.

\section{Inner model}

The influence test on the structural test model in the PLS (Partial Least Square) method consists of the coefficient of determination, t-statistic value, and parameter coefficient values. The results of testing the inner model are described in Table 4.

\section{The Effect of Institutional Performance on Financial Resources}

The financial resources of dairy farmers are influenced by the institutional performance of dairy farmers by $41.6 \%$. Institutional performance affects financial resources positively and significantly by $0.414(3,668>1,653)$. This means that the institutional dairy farmers at KUB (Joint Business Group) Tirtasari Kresna Gemilang have a positive impact to the financial resources of dairy farmers. The higher the institutional performance, the greater the farmer's access to financial resources. Farmer access to financial resources at KUB Tirtasari Kresna Gamilang which is influenced by institutional performance consists of main income, income from dairy cattle business, income from businesses other than livestock, income from other livestock businesses, total income for daily necessities, total savings, ownership of calves, ownership of heifers, ownership of pregnant cows, ownership of production cows, and total population of cows that are kept (Amam et al., 2019).

Riszqina et al., (2014) states that business scale is very influential on livestock productivity and Asmara et al., (2017) productivity and profitability of large scale livestock businesses are higher when compared to small scale livestock businesses. Amam and Harsita (2019) state that one of the efforts to reduce the vulnerability aspects of livestock farming business is by developing livestock farming businesses. Livestock farming business development is influenced by various resources, one of which is financial resources (Amam et al., 2019).

\section{The Effect of Institutional Performance on Technological Resources}

The technological resources of dairy farmers are influenced by the institutional performance of dairy farmers by $40.5 \%$. Institutional performance affects technological resources positively and significantly by $36.7(3,425>1,653)$. This means that the institutional dairy farmers at KUB (Joint Business Group) Tirtasari Kresna Gemilang have a positive impact on the technological resources of dairy farmers. 
The higher the institutional performance, the greater the farmer's access to technological resources.

Farmer access to technological resources at KUB Tirtasari Kresna Gamilang, which is influenced by institutional performance, consists of selection of breeders (breeding), housing, milk marketing, and technology to increase milk production (Amam et al., 2019). Ali and Muwakhid (2014); Amam and Harsita (2019) stated that the knowledge and skills of beef cattle breeders from the aspect of intensive fattening production and management include the use of feeders, feeding strategies, housing techniques and maintenance management, and the mating system with Artificial Insemination (AI).

Zailzar et al. (2011) states that the factors causing the low productivity of ruminants in Indonesia are generally classified into breed, climate, feed, and maintenance management factors. Ramadan et al. (2015) added that problems that threaten the sustainability of dairy cattle businesses are limited forage, a decrease in the number of dairy farmers, low quality of milk, health and livestock diseases, and limited agribusiness facilities and infrastructure.

Table 2. Outer Loading Values

\begin{tabular}{|c|c|c|c|c|c|}
\hline Indicator & $\mathrm{X}$ & $Y_{1}$ & $\mathrm{Y}_{2}$ & $\mathrm{Y}_{3}$ & Results \\
\hline $\mathrm{X}_{1.1}$ & 0.912 & & & & valid \\
\hline $\mathrm{X}_{1.2}$ & 0.756 & & & & valid \\
\hline $\mathrm{X}_{1.3}$ & 0.884 & & & & valid \\
\hline $\mathrm{X}_{1.4}$ & 0.526 & & & & valid \\
\hline $\mathrm{X}_{1.5}$ & 0.714 & & & & valid \\
\hline $\mathrm{X}_{1.6}$ & 0.845 & & & & valid \\
\hline$Y_{1.1}$ & & 0.622 & & & valid \\
\hline$Y_{1.2}$ & & 0.906 & & & valid \\
\hline $\mathrm{Y}_{1.3}$ & & 0.546 & & & valid \\
\hline $\mathrm{Y}_{1.4}$ & & 0.732 & & & valid \\
\hline$Y_{1.5}$ & & 0.515 & & & valid \\
\hline$Y_{1.6}$ & & 0.628 & & & valid \\
\hline $\mathrm{Y}_{1.9}$ & & 0.824 & & & valid \\
\hline$Y_{1.10}$ & & 0.639 & & & valid \\
\hline $\mathrm{Y}_{1.11}$ & & 0.565 & & & valid \\
\hline $\mathrm{Y}_{1.12}$ & & 0.968 & & & valid \\
\hline$Y_{1.14}$ & & 0.833 & & & valid \\
\hline$Y_{2.1}$ & & & 0.714 & & valid \\
\hline $\mathrm{Y}_{2.4}$ & & & 0.677 & & valid \\
\hline $\mathrm{Y}_{2.5}$ & & & 0.865 & & valid \\
\hline$Y_{2.6}$ & & & 0.741 & & valid \\
\hline $\mathrm{Y}_{3.2}$ & & & & 0.885 & valid \\
\hline $\mathrm{Y}_{3.3}$ & & & & 0.623 & valid \\
\hline$Y_{3.4}$ & & & & 0.725 & valid \\
\hline$Y_{3.5}$ & & & & 0.526 & valid \\
\hline$Y_{3.7}$ & & & & 0.644 & valid \\
\hline$Y_{3.8}$ & & & & 0.836 & valid \\
\hline $\mathrm{Y}_{3.9}$ & & & & 0.784 & valid \\
\hline$Y_{3.10}$ & & & & 0.868 & valid \\
\hline
\end{tabular}

Note: value of outer loading after removing invalid indicator 
Table 3. The Results of Outer Model Test

\begin{tabular}{lcccc}
\hline \multicolumn{1}{c}{ Variable } & Notation & AVE & CA & $\mathrm{R}^{2}$ \\
\hline Institutional performance & $\mathrm{X}$ & 0.848 & 0.895 & \\
Financial resources & $\mathrm{Y}_{1}$ & 0.879 & 0.864 & 0.416 \\
Technological resources & $\mathrm{Y}_{2}$ & 0.732 & 0.756 & 0.405 \\
Physical resources & $\mathrm{Y}_{3}$ & 0.906 & 0.821 & 0.347 \\
\hline
\end{tabular}

Table 4. Inner model

\begin{tabular}{lll}
\hline \multicolumn{1}{c}{ Testing } & Value & Note \\
\hline Coefficient of determination (R2) & & \\
a. Economic resources & 0.416 & \\
b. Environmental resources & 0.405 & \\
c. Social resources & 0.347 & \\
t-statistic & & \\
a. $\mathrm{X} \rightarrow \mathrm{Y}_{1}$ & 3.668 & significant \\
b. $\mathrm{X} \rightarrow \mathrm{Y}_{2}$ & 3.425 & significant \\
c. $\mathrm{X} \rightarrow \mathrm{Y}_{3}$ & 2.234 & \\
Parameter coefficient & & \\
a. $\mathrm{X} \rightarrow \mathrm{Y}_{1}$ & 0.414 & positive effect \\
b. $\mathrm{X} \rightarrow \mathrm{Y}_{2}$ & 0.367 & positive effect \\
c. $\mathrm{X} \rightarrow \mathrm{Y}_{3}$ & 0.289 & positive effect \\
\hline
\end{tabular}

$t$ table: 1.653

\section{Effect of Institutional Performance on Physical Resources}

The physical resources of dairy farmers are influenced to the institutional performance of $34.7 \%$ dairy farmers. Institutional performance affects physical resources positively and significantly by $36.7(2,234>1,653)$. This means that the institutional dairy farmers at KUB (Joint Business Group) Tirtasari Kresna Gemilang have a positive impact to the physical resources of dairy farmers. The higher of institutional performance, the greater farmer's access to physical resources.

Farmers' access to physical resources at KUB Tirtasari Kresna Gemilang, which is influenced by institutional performance (Amam and Soetriono, 2020; Amam and Harsita, 2019), consists of cattle pens, transportation facilities, communication facilities, information facilities, land tenure, land use, availability of water sources, and availability of food sources (Amam et al., 2019). Hilmi et al. (2016) explained that the main obstacle in providing forage for animals is that production is not constant throughout the year. Feed shortages and year-round availability of feed are the main limiting factors in the low productivity of livestock (Mansyur et al., 2012; Harsita and Amam, 2019). One possible effort is to carry out a system of integration of plants with livestock. Kariyasa (2005) states that the main principle of integration of livestock plants is the existence of a mutually beneficial (synergistic) relationship between plants and livestock. Farmers use livestock manure as organic fertilizer for plants and utilize agricultural waste for animal feed.

\section{CONCLUSION}

The farmers access to financial, technological, and physical resources is affected by institutional performance of $0.414,0.367$, and 0.289 , respectively. The conclusion of the study shows that institutional performance has a positive and significant effect on farmers' access to financial, technological and physical resources.

\section{REFERENCES}

Amam, A., Fanani, Z., Hartono, B., \& Nugroho, B. A. (2019). Broiler livestock business based on partnership cooperation in Indonesia: 
The assestment of opportunities and business development. International Journal of Entrepreneurship, 23(4), 1-10.

Amam, A., Fanani, Z., Hartono, B., \& Nugroho, B. A. (2019). Identification on resources in the system of broiler farming business. Jurnal Ilmu Ternak Dan Veteriner, 24(3), 135-142. http:// dx.doi.org/10.14334/jitv.v24.3.1927

Amam, A., Fanani, Z., Hartono, B., \& Nugroho, B. A. (2019). Pengembangan usaha ternak ayam pedaging sistem kemitraan bagi hasil berdasarkan aksesibilitas peternak terhadap sumber daya. Jurnal Ilmu Dan Teknologi Peternakan Tropis, 6(2), 146-153. https://doi.org/10.3377 2/JITRO.V6I2.5578

Amam, A., Fanani, Z., Hartono, B., \& Nugroho, B. A. (2019). The power of resources in independent livestock farming business in Malang District, Indonesia. IOP Conferences Series: Earth And Environmental Science, 372, 1-10. http://doi.org/10.1088/175 51315/372/ 1/012055

Amam, A., Fanani, Z., Hartono, B., \& Nugroho, B. A. (2019). Usaha ternak ayam pedaging sistem kemitraan pola dagang umum: pemetaan sumber daya dan model pengembangan. Sains Peternakan, 17(2), 5-11. https://doi. org/10.20961/sainspet.v17i2.26892

Amam, A., \& Harsita, P. A. (2019). Aspek kerentanan usaha ternak sapi perah di Kabupaten Malang. AGRIMOR, 4(2), 26-28. https://doi.org/10.32938/ag.v4 i2.663

Amam, A., \& Harsita, P. A. (2019). Efek domino performa kelembagaan, aspek risiko, dan pengembangan usaha terhadap SDM peternak sapi perah. Sains Peternakan, 17(1), 5-11. https:// doi.org/10.20961/sainspet.v17i1.24266

Amam, A., \& Harsita, P. A. (2019). Pengembangan usaha ternak sapi perah: evaluasi konteks kerentanan dan dinamika kelompok. Jurnal Ilmiah Ilmu Ilmu Peternakan, 22(1), 23-34. https://doi.org/10.22437/jiiip. v22i1.7831

Amam, A., \& Harsita, P. A. (2019). Tiga pilar usaha tenak sapi perah: Breeding, feeding, and management. Jurnal Sain Peternakan Indonesia, 14(4), 431439. https://doi.org/10.31186/jspi.id. 14.4.431-439

Amam, A., Jadmiko, M. W., Harsita, P. A., \& Poerwoko, M. S. (2019). Model pengembangan usaha ternak sapi perah berdasarkan faktor aksesibilitas sumber daya. Jurnal Sain Peternakan Indonesia, 14(1), 61-69. https://doi. org/10.31186/jspi.id.14.1.61-69

Amam, A., Jadmiko, M. W., Harsita, P. A., Widodo, N., \& Poerwoko, M. S. (2019). Sumber daya internal peternak sapi perah dan pengaruhnya terhadap dinamika kelompok dan konteks kerentanan. Jurnal Ilmiah Peternakan Terpadu, 7(1), 192-200. https://doi. org/10.23960/jipt.v7i1.p192-200

Amam, A., Jadmiko, M. W., Harsita, P. A., \& Yulianto, R. (2019). Internal resources of dairy cattle farming business and their effect on institutional performance and business development. Journal of Animal Production, 21(3), 157-166. http://doi. org/10.20884/1.jap.2019.21.3.738

Amam, A., Jadmiko, M. W., Harsita, P. A., Yulianto, R., Widodo, N., Soetriono, \& Poerwoko, M. S. (2020). Usaha ternak sapi perah di Kelompok Usaha Bersama (KUB) Tirtasari Kresna Gemilang: Identifikasi sumber daya dan kajian aspek kerentanan. Jurnal Ilmu Peternakan Dan Veteriner Tropis, 10(1), 77-86. https://doi.org/ 10.30862 /jipvet.v10i1

Amam, A., Jadmiko, M. W., Harsita, P. A., Yulianto, R., \& Poerwoko, M. S. (2019). Biotechnology in cattle business in Indonesia. Journal by Innovative Scientifict Information \& Service Network, 16(2), 2151-2156.

Amam, A., \& Soetriono, S. (2019). Evaluasi performa kelembagaan peternak sapi perah berdasarkan aspek risiko bisnis dan pengembangan usaha. Jurnal Ilmu 
Dan Teknologi Peternakan Tropis, 6(1), 8-13. https://doi.org/10.33772/ JITRO.V6I1.5391

Amam, A., \& Soetriono, S. (2020). Peranan sumber daya dan pengaruhnya terhadap SDM peternak dan pengembangan usaha ternak di Kawasan Peternakan Sapi Perah Nasional (KPSPN). Jurnal Peternakan Indonesia, 22(1), 1-10. https://doi.org/ 10.25077/jpi.22.1.1-10.2020

Amam, A., Yulianto, R., Widodo, N., \& Romadhona, S. (2020). Pengaruh aspek kerentanan terhadap aksesibilitas sumber daya usaha ternak sapi potong. Livestock And Animal Research, 18(2), 97-107. https://doi. org/10.20961/lar.v18i2.42955

Andarwati, S., Rijanta, R., Widiati, R., \& Opatpatanakit, Y. (2017). Strategi penghidupan peternak sapi perah di lereng selatan Gunung api Merapi pasca erupsi 2010. Buletin Peternakan, 41(1), 91-100. https:// doi.org/10.21059/buletinpeternak.v41 i1.12768

Asmara, A., Purnamadewi, Y. L., \& Lubis, D. (2017). The relationship analysis between service performances of milk producer cooperative with the dairy farm performance of members. Media Peternakan, 40(2), 143-150. https:// doi.org/10.5398/medpet.2017.40.2.143

Harsita, P. A. \& Amam. (2019). Permasaalahan utama usaha ternak sapi potong di tingkat peternak dengan pendekatan Vilfredo Pareto Analysis. Seminar Nasional Teknologi Peternakan Dan Veteriner 2019, 241250. http://dx.doi.org/10.14334/Pros. Semnas.TPV-2019-p.241-250

Hasdi, A. A., Fuah, A. M., \& Salundik Salundik. (2015). Analisis keberlanjutan peternakan sapi perah di Wisata Agro Istana Susu Cibugary di Pondok Ranggon Capayung Jakarta Timur. Jurnal Ilmu Produksi Dan Teknologi Hasil Peternakan, 3(3), 157-165.
Hilmi, M., Haq, E. S., \& Panduardi, F. (2016). IBM pemberdayaan kelompok ternak kambing etawa melalui pelatihan dan pendampingan dalam produksi silase sebagai pakan ternak alternatif di desa Wongsorejo. $J$ Dinamika, 1(2), 70-76. https://doi. org/10.25047/j-dinamika.v1i2.280

Kariyasa, K. (2017). Sistem integrasi tanaman-ternak dalam perspektif reorientasi kebijakan subsidi pupuk dan peningkatan pendapatan petani. Jurnal Analisis Kebijakan Pertanian, 3(1), 68-80. https://doi.org/10.21082/ akp.v3n1.2005.68-80

Mansyur., Dhalika, T., \& Islami, R. Z. (2012). Implementasi strategi dan teknologi kecukupan pakan sepanjang tahun untuk penyembangan peternakan sapi perah di Desa Sukawargi dan Cidatar Kecamatan Cisurupan Kabupaten Garut. Dharmakarya: Jurnal Aplikasi Ipteks Untuk Masyarakat, 1(2), 64-73. https://doi.org/10.24198/DHARMAK ARYA.V1I2.8198

Morton, G. D. (2019). The power of lump sums: Using maternity payment schedules to reduce the gender asset gap in households reached by Brazil's Bolsa Família conditional cash transfer. World Development, 113, 352-367. https://doi.org/10.1016/j.wo rlddev.2018.08.012

Ramadhan, D. R., Mulatsih, S., \& Amin, A. A. (2016). Keberlanjutan sistem budi daya ternak sapi perah pada peternakan rakyat di Kabupaten Bogor. Jurnal Agro Ekonomi, 33(1), 51-72. https://doi.org/10.21082/jae.v 33n1.2015.51-72

Riszqina, R., Isbandi, I., Rianto, E., \& Santoso, S. I. (2014). The analysis of factors affecting the performance and benefit of karapan (racing) cattle business in Madura Island, East Java, Indonesia. Journal of the Indonesian Tropical Animal Agriculture, 39(1), 65-72. https://doi.org/10.14710/jitaa. 39.1.65-72 
Sutanto, A., \& Hendraningsih, L. (2013). Analisis keberlanjutan usaha sapi perah di Kecamatan Ngantang Kabupaten Malang. Jurnal Gamma, 7(1), 1-12.

Usman, A., \& Muwakhid, B. (2017). Upaya pengembangan sapi potong menggunakan pakan basal jerami padi di Desa Wonokerto, Dukun, Gresik. Jurnal Dedikasi, 14(1), 65-72.
Zailzar, L., Sujono, Suyatno, \& Yani, A. (2012). Peningkatan kualitas dan ketersediaan pakan untuk mengatasi kesulitan di musim kemarau pada kelompok peternak sapi perah. Jurnal Dedikasi, 8(5), 15-28. https://doi.org/ 10.22219/dedikasi.v8i0.692 